\title{
Postharvest Physiology and Storage of Golden Apple (Spondias cythera sonnerat or Spondias dulcis forst): A Review
}

\section{Mohammed $\mathbf{M}^{1 *}$, Bridgemohan $\mathrm{P}^{2}$, Mohamed $\mathbf{M S}^{2}$, Bridgemohan $\mathbf{R S H}^{3}$ and Mohammed $\mathbf{Z}^{4}$}

${ }^{1}$ Faculty of Food and Agriculture, Department of Food Production, University of the West Indies, Trinidad and Tobago

${ }^{2}$ Biosciences Agriculture and Food Technology, The University of Trinidad and Tobago, Waterloo Research Campus, Carapichaima, Trinidad and Tobago

${ }^{3}$ Georgia College and State University, GA, USA

${ }^{4}$ State University of New York (SUNY), Plattsburg, New York, USA

\begin{abstract}
The golden apple (Spondias dulsis forst. syn. Spondias cytherea Sonn.) originated in the Society of Islands in the South Pacific and widely distributed in the Caribbean, Florida Keys, Hawaii, Venezuela and Central America and has successfully adapted as a natural part of the landscape and diet. Golden apple fruits at the mature-green, semi-ripe and ripe stages of maturity are utilized in the fresh and processed states and are a major export fruit and foreign exchange earner for many Caribbean islands. The fruit is an ovoid drupe with a spiny stone, climacteric in nature and exists in two forms: the large type (diameter 5-6 cm, length 9-10 cm, average weight $200 \mathrm{~g}$ ) and the miniature or dwarf type (diameter $4-5 \mathrm{~cm}$, length $5-6 \mathrm{~cm}$, average weight $65 \mathrm{~g}$ ). Golden apple fruits stored under ambient conditions require 6-9 days to undergo ripening from the mature-green stage to the golden yellow full ripe stage compared to storage under refrigerated conditions where an additional 6-10 days are needed to achieve the same objective. Mature-green fruits have a total soluble solids (TSS) content of $4.6-10.9 \%$, total titratable acidity (TTA) of $0.45-1.07 \%$ and TSS/ TTA of 7.7-19.1. Fully ripened fruits on the other hand have 9-16.3\% TSS, 0.53-1.16\% TTA and 8.7-22.4 TSS: TTA. Golden apple fruits are an excellent source of antioxidants with phenolic compounds averaging $349.5 \mathrm{mg}$ gallic acid per $100 \mathrm{~g}^{-1}$ fresh weight and vitamin C of $52.0 \mathrm{mg}$ per $100^{-1}$ fresh weight. Golden apple fruit of both genetic lines are very sensitive to chilling injury $(\mathrm{Cl})$. Waxing effectively delayed the appearance of $\mathrm{Cl}$ symptoms such as pitting. The ripened golden apple fruits are used to make jams, preserved jellies, nectars and sparkling beverages. Unripe fruits are eaten in curries, or as green salads, pickles, chutneys, sauces and amchar. More recently, the fruit skin has been recognized as a novel source of pectin and utilized as a gelling agent in jams, confectionary and bakery fillings as well as a stabilizer in yogurts and milk drinks.
\end{abstract}

Keywords: Ripening; Senescence; Maturation; Chilling injury

\section{Introduction}

Golden apple can be considered as an exotic fruit which imparts a distinct Caribbean flavor when utilized in a variety of fresh beverages and dishes. Further, in view of the small acreages under cultivation and not classified as a plantation crop, it received limited attention in industrial processing. However, until the recent introduction of dwarf varieties and newly introduced improved lines, interest in production has increased. This moreso as the demand for fresh fruit in the United States of America and Canada has quadrupled in the last decade by the West Indian diaspora due to the processing potential of the fruit into juices, nectars, jams and jellies [1]. While there are several production bulletins and journal articles on the agronomy of the fruit, less emphasis is placed on the pre-harvest, postharvest and development of valueadded food products for the regional and extra regional markets. This review collates all available literature on the topic including personal communication with expertise in the subject area to analyze and chart a course of research and development to fill the gap in the postharvest physiology and storage of the crop.

\section{Morphology and structure}

The golden apple (Spondias cythera Sonnerat or Spondias dulcis Forst.), is also referred to as otaheite apple, ambarella, polynesian plum, cajamanga, jew plum, june plum and pommecythere. It belongs to the Anacardiaceae family which also includes several important tropical fruit trees such as mango (Mangifera indica L.) and cashew (Anacardium occidentale L.) and is native to Polynesia. Introduced in Jamaica in 1782, the fruit is now cultivated throughout the Caribbean, Asia, South and Central American regions and to a lesser extent, in Africa [2].

Of the two distinct types of golden apple fruit, the larger type which is more popular is borne on trees attaining a height of 9-25 m whilst the miniature or dwarf type is from trees about 1.5-3 m (Figure 1). Fruit shape vary from oval to round or pear-shaped for both types, and fruit size range from about $5-6 \mathrm{~cm}$ in diameter and $9-10 \mathrm{~cm}$ in length with an average weight of $200 \mathrm{~g}$ for the large type [3]. The miniature or dwarf type is about $4-5 \mathrm{~cm}$ in diameter and 5-6 $\mathrm{cm}$ in length and averages $65 \mathrm{~g}$ in weight [4-6]. The trees of both types are rapid-growing, upright with a rigid and symmetrical shape. It is a stately ornamental with deciduous, pinnate leaves 20-60 cm in length, composed of 9-25 glossy, elliptic or obovate-oblong leaflets $6.25-10 \mathrm{~cm}$ long, which are finely toothed towards the apex [2]. Small, inconspicuous, whitish flowers are borne in large terminal panicles which are assorted male and female and perfect in each cluster. Long-stalked fruits are borne in clusters of a dozen or more, with thin but tough skin, often russetted. While the fruit is still firm, the flesh is crisp, juicy and sub acid, and has a somewhat pineapple-like fragrance and flavor [2,3]. If allowed to soften, the aroma and flavor become musky and the flesh difficult to slice because of conspicuous and tough fibres or spines extending from the rough ridges of the 5-celled, woody core $[2,4]$.

*Corresponding author: Mohammed M, Faculty of Food and Agriculture, Department of Food Production, University of the West Indies, Trinidad and Tobago, Tel: 18687973103; E-mail: mohd2332@hotmail.com

Received November 20, 2017; Accepted December 08, 2017; Published Decembe 15,2017

Citation: Mohammed M, Bridgemohan P, Mohamed MS, Bridgemohan RSH Mohammed Z (2017) Postharvest Physiology and Storage of Golden Apple (Spondias cythera sonnerat or Spondias dulcis forst): A Review. J Food Process Technol 8: 707. doi: 10.4172/2157-7110.1000707

Copyright: ( 2017 Mohammed M, et al. This is an open-access article distributed under the terms of the Creative Commons Attribution License, which permits unrestricted use, distribution, and reproduction in any medium, provided the original author and source are credited. 


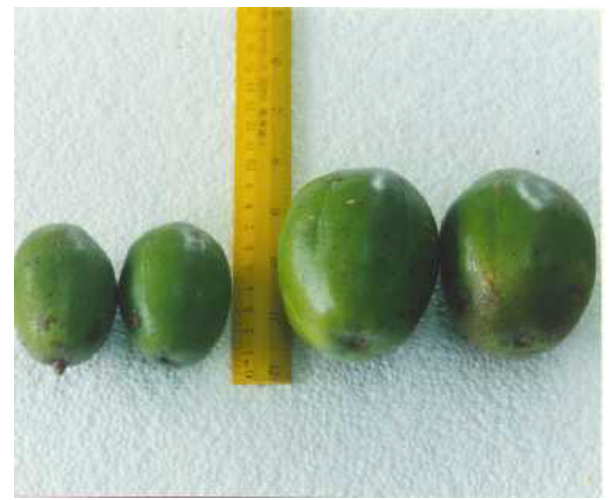

Figure 1: Mature green golden apples of the miniature and large types [19]

\section{Economic value and market opportunities}

The golden apple fruit of both types can be utilized in similar ways in the fresh and processed forms. Extra-regional export markets became established in the late 1980's and the large type fruit is now exported from several Caribbean countries. A number of value-added products such as amchar, chutney, pickles (sweet and sour), and wine are in demand in the ethnic markets in Canada, United States and United Kingdom. However, the miniature or dwarf golden apple fruit remains unexploited although it has great potential for domestic utilization as well as a foreign exchange earner in overseas markets. The advantages of the dwarf trees include: availability of fruits throughout the year compared to the large fruit type which is seasonal; trees are less cumbersome to harvest due to the significant height difference; early bearing; establishment of very high planting densities giving higher yields per unit area in contrast to the large type trees; the miniature fruits lend itself more easily to certain types of processing due to the softer seed and easy-peel nature of the pericarp $[1,3,4]$

\section{Nutritive value and medicinal benefits}

The food value of golden apple fruits per $100 \mathrm{~g}$ of edible portion is 157.30 calories; total solids range from $14.53 \%$ to $40.35 \%$; moisture $59.65 \%$ to $85.47 \%$, protein $0.50 \%$ to $0.80 \%$; fat $0.28 \%$ to $1.79 \%$, sugar $8.05 \%$ to $10.54 \%$, total titratable acidity $0.47 \%$, crude fibre $0.85 \%$ to $3.60 \%$ and vitamin C content $42 \mathrm{mg} / 100 \mathrm{~g}$ of raw pulp. It is a good source of iron. Unripe fruits contain $9.76 \%$ pectin [2]. The consumption of fresh golden apple fruit is increasing based on its nutraceutical properties against diabetes mellitus, indigestion, urinary tract infections, hypertension and hemorrhoids [7].

\section{Pre-harvest factors affecting fruit quality}

Golden apple fruits of both genetic lines grown in regions of high humidity experience problems associated with the fungal disease anthracnose (Colletotricum gloeosporoides). However, trees cultivated in areas where the average rainfall is $2000 \mathrm{~mm}$ and altitude of $150 \mathrm{~m}$ above sea level are generally smaller in size but are less susceptible to disease problems [6]. Mites, scales and sooty mould affect the pericarp of the fruits thus compromising its appearance, while anthracnose, gummosis and bacterial spots affect the extrinsic and intrinsic quality of the fruits [8]. Golden apple trees grown in the Caribbean islands are usually propagated from non-selected materials and therefore the production and quality of fruits tend to be highly inconsistent [6]. Andall and Baldeo [9] investigated the effect of fruit and inflorescence pruning on fruit size and yield of dwarf golden apple fruits and found increased fruit size but reduced yield. Inflorescence pruning on the other hand, reduced fruit size as well as fruit yield.
The golden apple tree is tolerant to drought, but under such conditions the trees remain stunted and produce fewer and undersized fruits [2]. The tree requires full sunlight for optimum tree and fruit growth [10]. However, young trees require light shade in the early years of establishment [11]. Mature trees are somewhat brittle and prone to damage by strong winds therefore a sheltered location is preferred [2]. As such, it is common for golden apple trees to be established as an intercrop in cocoa plantations, or as a single crop in backyard orchards [12]. The trees exhibit a short dormant period in the early dry season as their leaves turn light yellow and then senesces and abort. Flowering is subsequently initiated with the early rain and fruits ripen in 6-7 months after flowering [13]. The trees produce flowers 4 years after planting and continue to produce good yields after 25 years. Accordingly, Geurts et al. [14] reported yields per tree of 800-900 fruits with an average weight of $270-450 \mathrm{~kg}$, but in subsequent investigations Bauer et al. [13] claimed yields as high as $900 \mathrm{~kg}$.

\section{Postharvest physiology}

Growth and development: Graham et al. $[15,16]$ reported on the growth and developmental changes of the miniature golden apple. They found that the miniature golden apple fruit exhibited a single sigmoid growth curve based on values for fruit length, diameter and fresh mass. During the early stages of fruit growth from fruit-set up to eleven weeks the growth was very rapid for fruit length, fruit diameter and fresh mass and continued for an additional two weeks into the exponential growth phase which lasted until 13 weeks. This phase was followed by a phase of relatively constant growth for all three-dimension variables from the 13th to 23rd week until harvest. It was found that harvest maturity or the mature-green stage was attained at 19-21 weeks after fruit-set as indicated by constant fruit mass of 64-68 g/fruit in the miniature or dwarf golden apple fruit. The traditional large type golden apple fruit trees have fruits with an average weight of 140-224 g/fruit, fruit length of $7.5 \mathrm{~cm}$ and width of $6.3 \mathrm{~cm}$ [13]. However, fruits in Grenada and St. Vincent in the Caribbean have been observed to weigh as much as 450 $\mathrm{g}$ [6]. Franquin et al. [17,18] characterized mature-green fruits grown in Martinique (French West Indies) with average length, diameter and weight being $71 \mathrm{~mm}, 54 \mathrm{~mm}$ and $116.5 \mathrm{~g}$ respectively.

Maturity indices and quality attributes: Golden apple fruits of both types, miniature or large, are required in the local, regional and extra regional markets when mature-green, unripe, firm, free from mould surface disease, absence of scarring ( $<15 \%$ infection) and no mechanical damage $[1,3,19,20]$. Fruit of both types are oval, round or pear-shaped and this variation in fruit shape can exist in a single cluster of fruit in both genetic lines. For the large fruit, a minimum weight $(150 \mathrm{~g})$ and length $(6 \mathrm{~cm})$ is required compared to the miniature type where a minimum weight $(60-65 \mathrm{~g})$ and length $(45 \mathrm{~cm})$ is acceptable for most markets. Mature green fruits are selected based on flesh, skin color and gloss. Upon maturity, the flesh color changes from pale green to cream and on ripening to yellow. Skin colour changes from dark green with minimal gloss to pale glossy green at maturity, and then to golden yellow at ripening [1].

Respiration, ethylene production and ripening: The respiratory patterns during growth and development for both fruit types are typical of a climacteric fruit $[4,21]$. For miniature golden apple fruits Graham et al. [15] indicated that the initiation of a climacteric rise in respiration occurred at 21-23 weeks after fruit-set, when color break was observed and ripening progressed thereafter. Some $85 \%$ to $100 \%$ of miniature golden apple fruits fell from the plants between maturation and ripening. No ethylene was detected in fruit up to color-break, while still attached to the plant. However, once detached, fruit ripened rapidly 
with the production of ethylene and increased respiration rates within 2-5 days. On the initiation of fruit ripening, there were major declines in fruit firmness and starch, total titratable acidity (TTA) and vitamin $\mathrm{C}$ contents. These changes were accompanied by considerable increases in total and reducing sugar contents, soluble solids concentration, $\mathrm{pH}$ and sugar-acid ratios (Figure 2 and Table 1). Organoleptic tests indicated that miniature golden apple fruits received acceptable ratings for flavor and texture when harvested 19-23 weeks after fruit-set [16]. In the miniature golden apple fruits during the exponential growth phase Graham et al. [15] observed a decline in respiration rates with increased fruit development, from $52.61 \mathrm{mg} \mathrm{kg}^{-1} \mathrm{~h}^{-1}, 5$ weeks after fruitset to about $25.45 \mathrm{mg} \mathrm{CO}_{2} \mathrm{~kg}^{-1} \mathrm{~h}^{-1}$ eight weeks later. The high rates of respiration detected during the early stages of fruit development was likely related to intense cellular activity, particularly high rates of cell division, cell enlargement and differentiation in the fleshly tissue of the developing fruit [22]. Respiration rates which decreased throughout the exponential growth phase continued to decline and attained a preclimacteric minimum of $17.25 \mathrm{mg} \mathrm{CO}_{2} \mathrm{~kg}^{-1} \mathrm{~h}^{-1} 4$ weeks later at colorbreak [16].

Mature miniature golden apple fruit, harvested at 19 weeks after fruit-set developed the changes characteristic of proper ripening. Fruits were ripened fully within $5-7$ days at $32^{\circ} \mathrm{C}$ with the development of a deep yellow to orange skin color and soluble solids concentration of between 120 to $130 \mathrm{~g} \mathrm{~kg}^{-1}$. In contrast, fruit harvested earlier developed

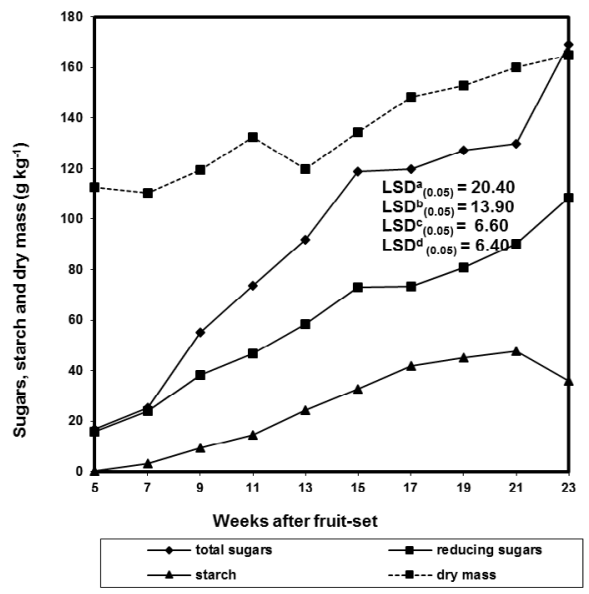

Figure 2: Changes during the growth and development of miniature golden apple fruit. Total sugars, reducing sugars, starch and dry mass. LSD: $a=$ Total sugars, $b=$ Reducing sugars, $c=$ Starch, $d=$ Dry mass. Level of significance was $(P<0.001)$ for starch, total and reducing sugars $(P<0.01)$ for dry mass $[4]$.

\begin{tabular}{|c|c|c|c|c|c|}
\hline $\begin{array}{c}\text { Weeks after } \\
\text { fruit-set }\end{array}$ & $\mathbf{S S C}\left(\mathbf{g ~ k g}^{-1}\right)$ & TTA $\left(\mathbf{g ~ k g}^{-1}\right)$ & $\mathbf{p H}$ & $\begin{array}{c}\text { Vitamin C } \\
\left.\mathbf{( g ~ k g}^{-1}\right)\end{array}$ & $\begin{array}{c}\text { Sugar acid } \\
\text { ratio }\end{array}$ \\
\hline 5 & $65.80^{\mathrm{a}}$ & $15.80^{\mathrm{b}}$ & $2.48^{\mathrm{a}}$ & $0.05^{\mathrm{a}}$ & $4.16^{\mathrm{a}}$ \\
\hline 7 & $83.30^{\mathrm{bc}}$ & $18.10^{\mathrm{a}}$ & $2.53^{\mathrm{a}}$ & $0.08^{\mathrm{b}}$ & $4.61^{\mathrm{ab}}$ \\
\hline 9 & $69.20^{\mathrm{a}}$ & $14.80^{\mathrm{bc}}$ & $2.67^{\mathrm{b}}$ & $0.09^{\mathrm{b}}$ & $4.68^{\mathrm{ab}}$ \\
\hline 11 & $75.00^{\mathrm{ab}}$ & $14.50^{\mathrm{bc}}$ & $2.71^{\mathrm{b}}$ & $0.08^{\mathrm{b}}$ & $6.50^{\mathrm{c}}$ \\
\hline 13 & $70.00^{\mathrm{ab}}$ & $13.60^{\mathrm{cd}}$ & $2.68^{\mathrm{b}}$ & $0.09^{\mathrm{b}}$ & $5.16^{\mathrm{b}}$ \\
\hline 15 & $78.30^{\mathrm{ab}}$ & $12.40^{\mathrm{de}}$ & $2.72^{\mathrm{b}}$ & $0.09^{\mathrm{b}}$ & $6.31^{\mathrm{c}}$ \\
\hline 17 & $73.30^{\mathrm{ab}}$ & $11.00^{\mathrm{e}}$ & $2.75^{\mathrm{b}}$ & $0.11^{\mathrm{c}}$ & $6.66^{\mathrm{c}}$ \\
\hline 19 & $75.00^{\mathrm{ab}}$ & $7.10^{\mathrm{f}}$ & $2.77^{\mathrm{b}}$ & $0.10^{\mathrm{bc}}$ & $10.56^{\mathrm{d}}$ \\
\hline 21 & $75.00^{\mathrm{ab}}$ & $6.80^{\mathrm{f}}$ & $2.89^{\mathrm{c}}$ & $0.14^{\mathrm{d}}$ & $11.03^{\mathrm{d}}$ \\
\hline 23 & $93.30^{\mathrm{c}}$ & $6.70^{\mathrm{f}}$ & $3.01^{\mathrm{d}}$ & $0.09^{\mathrm{b}}$ & $13.93^{\mathrm{e}}$ \\
\hline
\end{tabular}

Means followed by the same letter(s) are not significantly different $(P<0.05)$.

Table 1: Compositional changes in miniature golden apple fruit during growth and development [4]

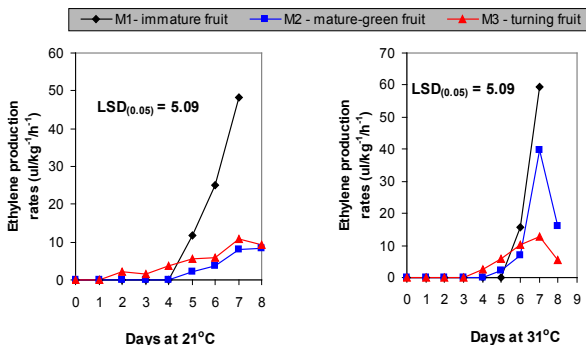

Figure 3: Ethylene production of miniature golden apple fruits at three stages of fruit maturity during storage [4].

a pale yellowish skin color and peak soluble solids concentration of $100 \mathrm{~g} \mathrm{~kg}^{-1}$. This demonstrated that fruit development at stages prior to 133 days, resulted in immature while the mature-green stage of development was attained in fruit older than 132 days after fruit-set. In another investigation, Graham et al. $[15,16]$ examined the changes in respiration, ethylene production rates and physicochemical quality attributes of miniature golden apple fruits during storage at $21^{\circ} \mathrm{C}$ and $31^{\circ} \mathrm{C}$ during three stages of maturity (Figure 3 ). The number of days that fruit took to attain full skin color development associated with ripening varied with storage temperature and stage of development. Accordingly, at $21^{\circ} \mathrm{C}$ and $31^{\circ} \mathrm{C}$, immature fruit took 8 and 6 days, mature-green fruit 10 and 8 days and breaker fruit 7 and 6 days respectively to attain full skin color development. At both temperatures increased skin color was associated with a climacteric pattern of respiration and higher soluble solids concentration and total sugar content. Generally, at the climacteric, simultaneous peaks in $\mathrm{CO}_{2}$ and $\mathrm{C}_{2} \mathrm{H}_{4}$ production were obtained for breaker fruit after 7 days but after 8 days for both immature and mature-green fruit. Storage at $21^{\circ} \mathrm{C}$ delayed the initiation of climacteric $\mathrm{CO}_{2}$ production by immature fruit and the initiation of climacteric $\mathrm{C}_{2} \mathrm{H}_{4}$ production by both mature-green and breaker fruit [4]. Daulmerie [21] investigated postharvest respiratory activity of the full mature large type golden apple fruit under ambient conditions $\left(28^{\circ} \mathrm{C}\right)$ over a 12 days period. A typical climacteric pattern of respiration was $24 \mathrm{~m} / \mathrm{kg}^{-1} \mathrm{hr}^{-1}$ which decreased rapidly to $15.5 \mathrm{~m} /$ $\mathrm{kg}^{-1} \mathrm{hr}^{-1}$ by day 3 and the fruits were still green. Beyond this period up to day 7 , noticeable changes in the green skin color to light cream color were visible. The climacteric rise was then initiated after which $\mathrm{CO}_{2}$ levels increased dramatically from $19 \mathrm{~m} / \mathrm{kg}^{-1} \mathrm{hr}^{-1}$ to $35 \mathrm{~m} / \mathrm{kg}^{-1} \mathrm{hr}^{-1}$ after 9 days when fruits were ripe and coinciding with the climacteric peak. The decrease in $\mathrm{CO}_{2}$ to $24 \mathrm{~m} / \mathrm{kg}^{-1} \mathrm{hr}^{-1}$ on day 10 represented the climacteric decline or post-climacteric. Evidence of over-ripening was noted after 11 days at $28^{\circ} \mathrm{C}$. Daulmerie [21] concluded that there is an apparent delay of golden apple fruits (large type) to undergo ripening while still attached to the parent tree. One such theory she postulated was that an unknown inhibitor is probably produced in the tree which migrates into the fruit while still attached thereby preventing the fruit from reacting to ripening inducers such as ethylene. Furthermore, it could be articulated that tree-ripe of golden apple fruit is possibly activated by fungal growth and perhaps the inhibitor is metabolized by the fungus [20].

\section{Postharvest management affecting quality}

Temperature management: Golden apple fruits are classified as having a high rate of respiration comparable to other tropical fruits such avocado and papaya. The rate of respiration and evolution of respiratory heat could be reduced by harvesting fruit at a consistent stage of maturity, handling carefully to minimize physical damages during harvesting, packing, loading and unloading operations. 
Likewise, packing in shallow, padded, well ventilated, light colored plastic crates, and placing packed fruits under shade or covering fruitfilled harvesting containers with broad leaves such as banana leaves are necessary. Efficient logistical arrangements to transport containers to the packing house in well covered, light colored tarpaulins and harvesting and packing fruits during cooler parts of the day would also result in a lower rate of respiration and obviously less evolution of respiratory heat. Hydro cooling to remove field heat should be undertaken within 45 minutes upon arrival at the packing house. Submerging fruits in tap water $\left(7^{\circ} \mathrm{C}\right.$ to $\left.10^{\circ} \mathrm{C}\right)$ for one hour is an effective temperature management technique [19]. Precooled fruits should be kept at a non-chilling temperature of $12^{\circ} \mathrm{C}$ to $13^{\circ} \mathrm{C}$ and relative humidity of $85 \%$ to $90 \%$ throughout the postharvest handling system to optimize quality and shelf life $[19,20]$.

Physical damage: Mature-green golden apples of both genetic lines are dense, firm, turgid and therefore extremely susceptible to all forms of physical damages at every stage of the postharvest handling system. At harvest, the dominant type of physical damage is due to punctures from the harvester's finger nails. The incidence of cracks, even hair line in nature are evident and becomes visible after fruits are hydro cooled or washed. Seepage and infiltration of water between the thin skin and flesh could eventually transform into watery soft spots that eventually culminate in fruit decay [20]. Overfilling or under filling of harvesting containers could induce compression, bruising and abrasions which serve as avenues for secondary bacterial and fungal infections. Ultimately, the impact of these physical damages becomes visible at a later stage during distribution and marketing and could therefore be regarded as latent in nature. Monitoring and implementing proper fruit handling techniques to reduce physical damage is paramount and could be achieved by selection of shallow well-padded containers and conveyor belts to minimize physical damages associated with fruit rolling and rubbing. The use of hand gloves is also recommended during harvesting, sorting and packing operations [20]. Daulmerie [21] estimated cumulative postharvest losses arising from physical damages at harvest, during transport and at washing could be as high as $8.4 \%$.

Transpiration: The rate of transpiration or moisture loss in golden apple fruits is a function of stage of maturity at harvest, storage temperature, relative humidity and storage duration [20]. Graham et al. [4] reported percentage fresh weight losses of miniature golden apple fruits at immature, mature-green and breaker stages over a 14day period at $9^{\circ} \mathrm{C}, 21^{\circ} \mathrm{C}$ and $31^{\circ} \mathrm{C}$ respectively. At all temperatures fresh weight losses were highest for immature followed by mature-green and least for breaker fruits. At all temperatures over 14 days fresh weight losses averaged $5.6 \%$ with no visible evidence of shriveling when stored in sealed low-density polyethylene bags. Likewise, Daulmerie [21] did not observe shriveling in the large type fruit even at $12 \%$ fresh weight losses. Modified atmosphere packaging (MAP) resulted in a significant reduction in fresh weight losses, as much as $50 \%$, compared to fruits stored in air as control fruits. Daulmerie [21] reported volume losses at storage temperatures when fruits were held at $8^{\circ} \mathrm{C}, 13^{\circ} \mathrm{C}$, $18^{\circ} \mathrm{C}$ and $28^{\circ} \mathrm{C}$ via transpiration and respiration but storage of fruits in sealed polyethylene bags accounted for less percentage volume losses compared to fruits kept in air. Mohammed and Wickham [3] contradicted claims by Daulmerie [21] that changes in fresh weight losses resulting in shriveling of fruits stored at $8^{\circ} \mathrm{C}$ were due to chilling injury which resulted in pitting, and mummification of fruits with holes arising from the collapse of the chilled cells beneath the surface. Mohammed and Wickham [3] indicated that symptoms associated with desiccation were manifested differently than for chilling injury. In their study golden apple fruit appearance was affected by extensive shriveling and development of longitudinal depressions and watersoaked areas. Thus after 3 days at $30^{\circ} \mathrm{C}$ golden apple fruits stored in paper bags (control) had $4.1 \%$ fresh weight losses which increased two-fold, 8 days later. Fruit storability was terminated with rapid decay after 11 days at $30^{\circ} \mathrm{C}$, the major symptom being dry rot, caused by Fusarium $s p$.

Atmosphere: Mohammed and Wickham [3] proposed that the altered atmosphere created by waxing and seal-packaging golden apple fruits markedly influenced chilling injury (CI) damage, percentage marketable and percentage decayed fruits during storage (Table 2 ). They concluded that waxing was more effective than low density polyethylene (LDPE) bags in alleviating CI damage in golden apple fruits. Visible symptoms of CI for waxed fruits were observed after 23 days at $5^{\circ} \mathrm{C}$ while those of LDPE packaged fruits were noticeable after 19 days. Waxing also accounted for $8 \%$ and $6.3 \%$ more marketable fruits after 19 and 23 days at $5^{\circ} \mathrm{C}$ than LDPE packaged fruits. Percentage decayed fruits after 23 days at $5^{\circ} \mathrm{C}$ was $4.1 \%$ less for waxed compared with LDPE packaged fruits. When fruits from these two treatments were transferred for 1 day at $30^{\circ} \mathrm{C}$ waxed fruits had lower CI, pitting and decay than LDPE packaged fruits. Decay of fruits in LDPE bags from these treatments was enhanced as a result of condensation within the sealed bags and the warmer temperature obtained upon transfer to $30^{\circ} \mathrm{C}$. Bacterial soft rot caused by Eirwinia sp. dominated these samples.

\section{Physiological disorders}

Chilling injury: Mohammed and Wickham [3] investigated the effects of modified atmosphere packaging, storage temperature and duration on the keeping quality and chilling-tolerance of the large type golden apple fruits. It was confirmed that golden apple fruits are very chilling-sensitive when stored at $5^{\circ} \mathrm{C}$. Fruits stored in paper bags at $5^{\circ} \mathrm{C}$ showed visible symptoms of $\mathrm{CI}$ with tiny randomly scattered pits after 7 days but upon prolonged storage after 11 days resulted in moderate $\mathrm{CI}$ as the tiny pits coalesced to form a more concentrated pattern resulting in larger depressed areas characterized with a definite darkbrown discoloration. The injury became more apparent for fruits as early as 3 days at $5^{\circ} \mathrm{C}$ when subsequently transferred for an additional day at $30^{\circ} \mathrm{C}$. Thus, sheet pitting increased in severity and affected areas were water-soaked with individual spots flat or sunken with a small ring of normal tissue surrounding them. En masse, these areas had a dappled appearance and together with increasing levels of water loss, the sheet-pitted areas became sunken irregularly with a pebbly and grainy outlook. Mohammed and Wickham [3] also demonstrated that waxing delayed the appearance of pitting in the above storage regimes to 23 days and 15 days, respectively. Sheet pitting developed in LDPE bags packaged fruits after 19 days at $5^{\circ} \mathrm{C}$ and became more pronounced after holding at $30^{\circ} \mathrm{C}$ for one day (Table 3 ).

In addition to the symptoms observed, measurements of bioelectrical resistance (BER) and electrolyte leakage (EL) indicated

\begin{tabular}{|c|c|c|c|c|}
\hline \multirow{2}{*}{ Treatments } & \multicolumn{2}{|c|}{ Marketable fruits (\%) } & \multicolumn{2}{c|}{ Decayed fruits (\%) } \\
\cline { 2 - 5 } & $\mathbf{1 9}$ days & $\mathbf{2 3}$ days & $\mathbf{1 9}$ days & $\mathbf{2 3}$ days \\
\hline LDPE at $5^{\circ} \mathrm{C}$ & 26.6 & 10.6 & 11.1 & 16.2 \\
\hline LDPE at $5^{\circ} \mathrm{C}+1$ day at $30^{\circ} \mathrm{C}$ & 22.1 & 6.6 & 27.2 & 36.0 \\
\hline Wax at $5^{\circ} \mathrm{C}$ & 34.6 & 16.9 & 10.0 & 12.1 \\
\hline Wax at $5^{\circ} \mathrm{C}+1$ day at $30^{\circ} \mathrm{C}$ & 26.6 & 8.2 & 26.7 & 30.0 \\
\hline Paper bags at $5^{\circ} \mathrm{C}$ & 0.0 & 0.0 & 84.9 & 86.2 \\
\hline Paper bags at $5^{\circ} \mathrm{C}+1$ day at $30^{\circ} \mathrm{C}$ & 0.0 & 0.0 & 100.0 & 100.0 \\
\hline Paper bags at $30^{\circ} \mathrm{C}$ & 0.0 & 0.0 & 94.9 & 100.0 \\
\hline $\operatorname{LSD}_{(0.05)}$ & 4.1 & 1.4 & 4.49 & 4.0 \\
\hline
\end{tabular}

Table 2: Effect of packaging and waxing upon percentage marketable and decayed golden apple fruits after 19 and 23 days [3] 


\begin{tabular}{|c|c|c|c|c|c|c|c|c|}
\hline \multirow{3}{*}{ Treatments } & \multicolumn{8}{|c|}{ Bioelectrical resistance (kilohms) } \\
\hline & \multicolumn{6}{|c|}{ Storage period (days) 23 days } & \multicolumn{2}{|c|}{\begin{tabular}{|c|} 
Statistical \\
significance \\
23 days
\end{tabular}} \\
\hline & 3 & 7 & 11 & 15 & 19 & 23 & $\begin{array}{l}\text { LSD } \\
(0.05)\end{array}$ & Linear \\
\hline LDPE at $5^{\circ} \mathrm{C}$ & $70.00^{2}$ & 45.34 & 42.89 & 39.89 & 38.23 & 34.78 & 3.53 & * \\
\hline $\begin{array}{c}\text { LDPE at } 5^{\circ} \mathrm{C}+1 \text { day } \\
\text { at } 30^{\circ} \mathrm{C}\end{array}$ & 66.61 & 41.26 & 36.41 & 35.61 & 27.20 & 20.14 & 6.04 & * \\
\hline Wax at $5^{\circ} \mathrm{C}$ & 69.00 & 46.77 & 44.00 & 39.80 & 35.80 & 30.33 & 3.90 & * \\
\hline $\begin{array}{c}\text { Wax at } 5^{\circ} \mathrm{C}+1 \text { day at } \\
30^{\circ} \mathrm{C}\end{array}$ & 64.34 & 41.27 & 36.11 & 30.14 & 25.16 & 17.61 & 3.11 & ** \\
\hline Paper bags at $5^{\circ} \mathrm{C}$ & 63.90 & 38.00 & 27.40 & 25.77 & 26.77 & 23.97 & 2.43 & * \\
\hline $\begin{array}{c}\text { Paper bags at } 5^{\circ} \mathrm{C}+1 \\
\text { day at } 30^{\circ} \mathrm{C}\end{array}$ & 56.66 & 37.41 & 24.41 & 20.10 & ND & ND & 3.00 & ** \\
\hline Paper bags at $30^{\circ} \mathrm{C}$ & 74.67 & 51.53 & 36.00 & ND & ND & ND & 7.92 & * \\
\hline $\operatorname{LSD}_{(0.05)}$ & 3.53 & 1.01 & 7.68 & 4.01 & 1.40 & 2.29 & & \\
\hline
\end{tabular}

Table 3: Effect of packaging and waxing upon bioelectrical resistance (kilohms) of golden apple fruits during storage [3].

\begin{tabular}{|c|c|c|c|c|c|c|c|c|}
\hline \multirow{3}{*}{ Treatments } & \multicolumn{8}{|c|}{ Electrolyte leakage (\%) } \\
\hline & \multicolumn{6}{|c|}{ Storage period (days) } & \multicolumn{2}{|c|}{$\begin{array}{l}\text { Statistical } \\
\text { significance }\end{array}$} \\
\hline & 3 & 7 & 11 & 15 & 19 & 23 & $\begin{array}{c}\text { LSD } \\
(0.05)\end{array}$ & Linear \\
\hline LDPE at $5^{\circ} \mathrm{C}$ & $16.01^{z}$ & 18.18 & 20.18 & 27.43 & 46.45 & 52.47 & 2.00 & ** \\
\hline $\begin{array}{l}\text { LDPE at } 5^{\circ} \mathrm{C}+1 \text { day } \\
\text { at } 30^{\circ} \mathrm{C}\end{array}$ & 16.00 & 17.60 & 25.11 & 33.21 & 48.16 & 56.14 & 7.01 & ** \\
\hline Wax at $5^{\circ} \mathrm{C}$ & 14.74 & 20.98 & 21.18 & 21.58 & 29.03 & 58.61 & 5.61 & * \\
\hline $\begin{array}{c}\text { Wax at } 5^{\circ} \mathrm{C}+1 \text { day at } \\
30^{\circ} \mathrm{C}\end{array}$ & 14.70 & 24.61 & 29.23 & 30.14 & 35.16 & 37.19 & 4.40 & * \\
\hline Paper bags at $5^{\circ} \mathrm{C}$ & 15.76 & 17.53 & 39.34 & 52.87 & 52.89 & 59.45 & 4.07 & ** \\
\hline $\begin{array}{c}\text { Paper bags at } 5^{\circ} \mathrm{C}+1 \\
\text { day at } 30^{\circ} \mathrm{C}\end{array}$ & 17.61 & 21.62 & 44.66 & 56.79 & ND & ND & 10.59 & $* *$ \\
\hline Paper bags at $30^{\circ} \mathrm{C}$ & 10.94 & 36.74 & 32.13 & ND & ND & ND & 10.17 & * \\
\hline $\operatorname{LSD}_{(0.05)}$ & 1.98 & 2.48 & 0.79 & 3.06 & 5.01 & 3.14 & & \\
\hline \multicolumn{9}{|c|}{$\begin{array}{l}\text { zMean of } 10 \text { fruits/treatment } \times 4 \text { replicates } \\
{ }_{\text {, "* Linear value }}\end{array}$} \\
\hline
\end{tabular}

Table 4: Effect of packaging and waxing upon electrolyte leakage (\%) of golden apple fruits during storage [3].

\begin{tabular}{|c|c|c|c|c|c|}
\hline $\begin{array}{c}\text { Heat } \\
\text { treatments }\end{array}$ & $\begin{array}{c}\text { Marketable } \\
\text { fruit (\%) }\end{array}$ & $\begin{array}{c}\text { General } \\
\text { appearance }\end{array}$ & Decay (\%) & $\begin{array}{c}\text { Anthracnose } \\
\text { incidence (\%) }\end{array}$ & $\begin{array}{c}\text { Heat } \\
\text { injury } \\
\text { ratings }\end{array}$ \\
\hline $\begin{array}{c}46^{\circ} \mathrm{C} \text { for } 10 \\
\text { min. }\end{array}$ & 75 & 4 & 25 & 0 & 1 \\
\hline $\begin{array}{c}46^{\circ} \mathrm{C} \text { for } 15 \\
\text { min. }\end{array}$ & 0 & 2 & 20 & 0 & 4 \\
\hline $\begin{array}{c}46^{\circ} \mathrm{C} \text { for } 20 \\
\text { min. }\end{array}$ & 0 & 1 & 20 & 0 & 5 \\
\hline $\begin{array}{c}49^{\circ} \mathrm{C} \text { for } 10 \\
\text { min. }\end{array}$ & 0 & 1 & 15 & 0 & 5 \\
\hline $\begin{array}{c}49^{\circ} \mathrm{C} \text { for } 15 \\
\text { min. }\end{array}$ & 0 & 1 & 25 & 0 & 5 \\
\hline $\begin{array}{c}49^{\circ} \mathrm{C} \text { for } 20 \\
\text { min. }\end{array}$ & 0 & 1 & 30 & 0 & 5 \\
\hline $\begin{array}{c}\text { Untreated } \\
\text { control }\end{array}$ & 35 & 2 & 65 & 25 & 1 \\
\hline
\end{tabular}

${ }^{x}$ Heat injury ratings: 1: None; 2: Slight; 3: Moderate; 4: Severe; 5: Very severe 'General appearance ratings: 1: Very poor; 2: Poor; 3: Fair; 4: Good; 5: Excellent

Table 5: Effect of heat treatments on selected quality attributes of miniature golden apple fruits stored at $22^{\circ} \mathrm{C}$ for 6 days [4]. that severe membrane damage had occurred by 7 days storage at $5^{\circ} \mathrm{C}$ for all treatments (Tables 4 and 5). Thus, the inverse relationship encountered for bioelectrical resistance and electrolyte leakage provided a useful objective measure of the onset of CI prior to the appearance of CI symptoms.

This relationship proved to be a more accurate determination of the actual time-sequence for incipient $\mathrm{CI}$ in fruits prior to visible external evidence of symptom expression and was therefore considered to be used as an index of CI. However, Mohammed and Wickham [3] investigation confirmed an inverse relationship between BER and EL proceeded in a likewise manner for fruits held at $5^{\circ} \mathrm{C}$ and $30^{\circ} \mathrm{C}$ respectively. They proposed that fruit ripening and senescence initiated and contributed to the loss in membrane integrity. Thus, changes in visual color from green to yellow accompanied by a distinct high-scented aroma at $30^{\circ} \mathrm{C}$ indicative of advanced fruit ripening was notably absent in chill-injured fruits stored at $5^{\circ} \mathrm{C}$. Graham et al. [23] in their investigation of the chilling sensitivity of miniature golden apple fruits harvested at three stages of maturity and stored at $9^{\circ} \mathrm{C}$ found that chilling injury symptoms were evident after 4, 6 and 10 days respectively for immature, mature-green and breaker-stage fruit. However, these fruits were stored at $4^{\circ} \mathrm{C}$ higher than the large type fruits used by Mohammed and Wickham [3]. Both miniature and large type fruits exhibited an inverse relationship between BER and EL as the severity of CI accelerated over time.

Other physiological disorders: Fruits of both genetic lines are susceptible to heat injury. Heat injury symptoms included extensive patches of scalds on the skin and the prevalence of hard lumps in the flesh of ripe fruit. This was reported by Graham et al. $[15,16]$ when they investigated the effects of hot water treatments prior to storage on the incidence of decay. Fruits heat-treated at $46^{\circ} \mathrm{C}$ for 15 or 20 minutes or at $49^{\circ} \mathrm{C}$ for 10,15 or 20 minutes exhibited symptoms consistent with heat injury described above, after 3-4 days or 1 day respectively when stored at $22^{\circ} \mathrm{C}$. These fruits were classified as unmarketable, however, $75 \%$ of fruits heat-treated at $46^{\circ} \mathrm{C}$ for 10 minutes were still marketable with no visible evidence of heat injury after 6 days at $22^{\circ} \mathrm{C}$ [16] (Table 5).

\section{Pathological disorders}

Both types of golden apple fruits are prone to microbial infection during the wet season resulting in high percentage of spoilage. Bauer et al. [13] reported the occurrence of small ( $8 \mathrm{~mm}$ in diameter) round black lesions on green fruit with gumming developing slowly on the fruit as well as other large black spots of $1.5 \mathrm{~cm}$ of diameter. These lesions usually remain superficial ( $3 \mathrm{~mm}$ deep) and do not cause fruit rotting or softening. When fruits ripen the infected area remains pale green and softens. Brown lesions with no gumming can be observed on ripe fruits which leads to rotting and identified as Colletotrichum gloeosporioides. A stem rot (Botryosphaeric sp.) caused by a bacterium also occurs on ripe fruits $[5,13]$.

Gumming (Pestalotiopsis sp.) on mature trees have been reported in several Caribbean islands $[5,8]$, as well as a resinous canker identified as Lasiodiplodia sp. [24]. A bacterial canker was identified as a pathogenic form of Xanthomonas campestris pv. Magiferae indica [25]. Sooty mould due to Tripospermum sp. is common on the fruit skin [13]. Samson [26] also reported on the incidence of Phytophthora $s p$. A fungus Sphacelema spondias was reported in Florida and Brazil causing round spots on the leaves and fruits [14].

Graham et al. [15] subjected miniature golden apples to a hot water treatment by dipping fruits for $46^{\circ} \mathrm{C}$ for 10 minutes and reported effective control of anthracnose infections. However, exposing fruits 
at the same temperature for 15 minutes also resulted in no incidence of anthracnose but heat injury was severe and this accounted for fruits rated as unmarketable.

\section{Insect pests and control}

Due to its dense lush vegetative nature, both genetic lines are predisposed to insect attack [1]. Severe caterpillar attacks could result in complete defoliation of trees. The leaves can also suffer from severe damage by specific beetles [27]. Two main beetles (Podontia punctata and Podontia affinis) cause considerable damage to leaves [14]. In India, the first beetles appear in June and defoliate the trees. Eggs, laid in clusters of 20-60, incubate for a period of 7-8 days; the life cycle is 3235 days. Some parasites of these beetles have been found as a nematode (Mernis) and a fungus (Cephalosporium). A foliar spray of spores of this fungus, or of $0.25 \%$ of malathion, in June/July gave effective control of the insect [28].

Bauer et al. [13] reported on the incidence of scale insects on immature green fruits primarily on the fruit peduncle and shoulder. Feeding by the scale insects is associated with the development of pale-colored, light green to yellow spots scattered on the green skin of the fruit. The incidence of scale insects coincided with early fruit development in the dry season and caused black sooty mould to be deposited on the green fruits.

Mite infestation during the early stages of fruit development can cause severe scarring with pale-brown to grey bands across the fruit surface which rendered fruits unfit for the export market [13]. Severe mite infestations create corky deposits at the blossom-end of the fruit culminating in deformed fruits. Bauer et al. [13] reported attacks by other insects such as ants, termites and beetles. Ants were linked to scale insect infestation, removing the honey dew as well as attracted to the gum and tree sap. Tree branches are prone to infestation by termites, epiphytes and bird vines on trees located in regions of high relative humidity and serve as nesting sites for minor pests like birds, millipedes, and lizards but are not significant causes of postharvest losses.

\section{Postharvest handling practices}

Harvest operations: The harvest season for the large type fruits according to Bauer et al. [13] is from August to November with the peak season approaching over September and October. Harvesting is done manually and therefore is very challenging and labor intensive for obtaining fruits from the large type trees as opposed to miniature or dwarf type trees. The traditional large type trees which vary from 6-20 $\mathrm{m}$ in height with a trunk diameter $(50 \mathrm{~cm})$ demand creative harvesting techniques and devices. Fruits are harvested by climbing or using a picking pole with either a basket or bag attached as a catchment device. A pouch bag could also be used when climbing or when using a ladder. A rope-pulley system device can also be used to harvest larger loads. Mechanical devices such as an automatic platform trough could be adopted but these require heavy capital investment and maintenance costs [20]. These devices are further constrained by their inability to access trees on high or uneven terrains [29], or due to the small acreages and intercropping establishment systems [12].

Whatever harvesting aid is used, it is critical that fruits are not thrown or dropped to the ground. Golden apple fruits crack or split easily on impact resulting in postharvest losses [20]. Bauer et al. [13] estimated that losses of fruits at harvest in a study conducted in Grenada to be as high as 50\% and attributed this to shaking of branches causing fruits to drop on hard surfaces. Other contributing factors with such high losses were attributed to the acquisition of non-uniform fruit clusters accounting for the harvest of premature fruits. Additionally, difficulty in harvesters reaching fruits at the terminal ends of weak branches and fruit bruising caused by poor handling, inappropriate containers, over stacking and transportation over rough and hilly terrains resulted in physical damages. Daulmerie [21] estimated that the magnitude of postharvest losses at harvest to be $10 \%$ compared to Bauer et al. [13] estimates of losses almost five-fold more. Daulmerie [21] proclaimed that the main cause of rejects at harvest was associated with fruit deformity, mechanical damage and mite damage. Harvesting fruits within the same cluster at different stages of maturity often accounted for those that are immature to be more susceptible to mechanical damages such as bruises and cracks [20].

Packinghouse operations and practices: Golden apple fruits should be transported in shallow light-colored plastic crates and carefully loaded and stacked on trucks trays, covered with a white colored sanitized tarpaulin and taken to the packinghouse. Fruits should be washed in water containing 100-120 ppm sodium hydroxide solution [19]. In situations where fruits are harvested with sooty mould, Daulmerie [21] recommended a postharvest dip of $300 \mathrm{ppm}$ calcium hypochlorite for 15-35 minutes followed by rinsing in tap water. The soaking and washing procedures also remove dirt, surface debris and latex [29]. Fruits are air-dried prior to packing in card-board or fibreboard cartons. Fruits are sorted according to size with a minimum length of $6 \mathrm{~cm}$ and weight of $140 \mathrm{~g}$ [29]. Insect scarring as indicated by distinct brown scars on the fruit surface must not exceed $15 \%$ of the surface. Maximum weight of fruit in boxes should not exceed $18 \mathrm{~kg}$ which represent approximately 150 fruits. Packed fruits must be palletized and fork-lifted into a chill room and stored at $10^{\circ} \mathrm{C}$ to $12^{\circ} \mathrm{C}$ and $90 \%$ to 95\% relative humidity. Daulmerie [21] estimated that postharvest losses could reach as much as $10 \%$ to $11 \%$. This is in agreement with surveys conducted by Mohammed [20] and Bridgemohan [12]. They claimed that inadequate logistics at the packinghouse, inconsistent sanitation protocols as well limited infrastructure, packing line facilities and inexperienced packinghouse operators as major reasons for these losses.

Control of ripening and senescence: Under ambient conditions, physiologically matured golden apple fruits would commence ripening 2-4 days after harvest at the full mature green stage [4]. For the regional and overseas markets, fruits would need to be stored throughout the marketing chain under refrigerated conditions $\left(10^{\circ} \mathrm{C}\right.$ to $12^{\circ} \mathrm{C}, 90 \%$ to $95 \% \mathrm{RH})$. Being climacteric, the evolution and presence of $\mathrm{C}_{2} \mathrm{H}_{4}$ must be managed by ensuring that fruits are not kept with other climacteric fruits that are moderate to high producers of $\mathrm{C}_{2} \mathrm{H}_{4}$. Proper ventilation and sanitation protocols should be adhered and proper sorting to remove damaged fruits to reduce stress-induced $\mathrm{C}_{2} \mathrm{H}_{4}$ must be implemented. However, market demand for full-ripe fruits also exists. Accordingly, full mature green could be allowed to ripen under ambient conditions for 2-4 days or treated with ethrel (500 ppm) at $20^{\circ} \mathrm{C}$ to $22^{\circ} \mathrm{C}$ and $90 \%$ to $95 \%$ relative humidity for $1-1 \frac{1}{2}$ days and then subsequently stored at $7^{\circ} \mathrm{C}$ to $8^{\circ} \mathrm{C}$ and $90 \%$ to $95 \%$ relative humidity until retail display and consumption [19]. Full-ripe fruits stored at $7^{\circ} \mathrm{C}$ to $8^{\circ} \mathrm{C}, 90 \%$ to $95 \%$ relative humidity is less sensitive to chilling injury damage [19].

\section{Recommended Storage and Shipping Conditions}

Medlicott [29] recommended air-shipments over sea-transport. Mature-green golden apple fruits could be stored under ambient conditions for 20-24 hours prior to shipment. However, subsequent storage at $10^{\circ} \mathrm{C}$ to $12^{\circ} \mathrm{C}$ and $90 \%$ to $95 \%$ relative humidity following packinghouse operations are necessary to optimize quality and shelf 
life upon arrival of shipments at overseas market outlets. Golden apple fruits should not be stored in the same shipping container with fruits such as passion fruit, banana, plantains, papayas, which are prolific producers of $\mathrm{C}_{2} \mathrm{H}_{4}$. The presence of $\mathrm{C}_{2} \mathrm{H}_{4}$ would enhance ripening and senescence and incur ship-ripe losses.

Adherence to stacking protocols to promote a uniform flow of cool air in and around shipping loads as well as using properly sanitized containers should be implemented for high display quality at overseas destinations.

\section{Discussion on Processing Options}

\section{Processing options}

Both types of golden apple fruits are very versatile since they are eaten raw at the mature-green-stage and as a desert at the full-ripe stage. Beyond the mature-green stage the fruits could be processed in numerous ways. The crisp sliced flesh is stewed with a little water and sugar and then strained through a wire sieve to make a product similar to applesauce, but with a richer flavor and texture. With the addition of cinnamon or any other spices desired, this sauce can be cooked down to a thick buttery consistency. Unripe fruits can be processed into jelly, pickles or relishes, or used for flavoring sauces, soups and stews. In South-east Asia, fresh young golden apple leaves are appealingly acidic and consumed raw, steamed and eaten as a vegetable with salted fish and rice, or used as seasoning herb for various dishes. Green fruits when cooked with meat functions as a tenderizer [2]. In Malaysia, the golden apple fruit is eaten with shrimp paste which is a thick black salty-sweet sauce called "Layko". Fresh slices of the half-ripe fruit are currently served in fruit cocktails and salads due to its taste, nutritive value and fiber.

\section{Fresh-cut processing}

Fresh mature-green, breaker and ripe miniature and large type golden apple fruits have been utilized and subjected to fresh-cut or minimal processing options. Fruits are peeled and cut into quarters or halves with the spines and stone intact and eaten as a snack with or without a sprinkling of salt and selected ground or fresh-cut herbs such as shadon beni (Eryngium foetidum) and hot pepper (Capsicum frutescens) [20]. Unpeeled fresh-cut golden apple fruits can be sealed packaged in LDPE bags or stretch-wrapped over styrofoam trays and refrigerated at $7^{\circ} \mathrm{C}$ to $8^{\circ} \mathrm{C}$ for a maximum of 18 days. However, freshcut peeled or unpeeled fruits can be dipped-blanched in hot water $55^{\circ} \mathrm{C}$ to $60^{\circ} \mathrm{C}$ for $10-15 \mathrm{~min}$ and frozen. Such frozen samples would be stored for more than 8 months and subsequently cooked in curry and spices as a supplement to other meals [20]

\section{Other processing options}

The versatility of both types of golden fruits is reflected in the diverse range of value-added products, some of which have already been commercialized (kuchelar, sweet and sour pickles, amchar, chutney, jams, jellies, alcoholic and non-alcoholic beverages) while the potential for other products for commercialization, market expansion and exploitation as canned fruits in a syrup, nectars, novel pectin, starch hydrolysis and sauces also exist. Franquin et al. $[17,18]$ investigated the feasibility of making golden apple nectars at $13^{\circ} \mathrm{C}$ Brix using both amylolytic enzymes after gelatinization of the starch present in the juice and a green powder extracted from mature fruit peels as a natural coloring for nectars. The study was justified based on previous research which indicated the juice extracted from mature-green fruits had a high starch content which altered the visual appearance of the drink thereby promoting the formation of white sediments in the bottom of the container during storage. Also, the whiteness of the starch made the highly accepted olive-green color to fade. Pasteurization also contributed to further destruction of the olive-green color of the nectar. Franquin et al. $[17,18]$ solved these problems using two strategies. Firstly, for degrading starch and standardizing its content, the juice obtained after grinding and sieving was treated with an amyloglucosidase enzyme (AMG $300 \mathrm{~L}$ ) at various concentrations (200 $\mathrm{g} / \mathrm{t}, 700 \mathrm{~g} / \mathrm{t}, 2 \mathrm{~kg} / \mathrm{t}$ ) for 15 minutes at $60^{\circ} \mathrm{C}$ after starch gelatinization $\left(64^{\circ} \mathrm{C}\right.$ or $72^{\circ} \mathrm{C}$ for 15 minutes). Secondly, the treated juice was used to make nectar at $13^{\circ} \mathrm{C}$ Brix, using a green powder prepared from golden apple peels to embrace color of nectars. These new formulations provided the template for the production of less sweet nectars with a green color closer to that of the fresh fruit.

In a subsequent study, Franquin et al. [30] evaluated the effects of starch and cell wall degrading enzymes from mature-green golden apple fruits on juice residual starch and soluble sugar content. Starch and cell walls from mature-green golden apple fruits were purified and characterized. Starch contained $21.0 \%$ amylose, $78.1 \%$ amylopectin and $0.9 \%$ in other minor compounds. Cell walls represented $2.8 \%$ of the edible fresh matter and were mainly constituted of highly methylated pectic substances and cellulose. Their investigation further demonstrated that hydrolysis of golden apple starch is possible when pectinolysis occurred before amylolysis treatment, probably because of the fluidification of the medium by pecto cellulolytic enzymes. Furthermore, Pectinex Ultra SP-L was found to be the most efficient preparation to degrade the golden apple fruit pectins with $80 \%$ of the cell wall uronides being liberated from $120 \mathrm{mg} \mathrm{g}^{-1}$ of purified cell walls within 1 hour at $30^{\circ} \mathrm{C}$ and at a $\mathrm{pH}$ of 2.7 .

In other studies, Koubala et al. [31] investigated the potential of golden apple peels as a source of novel pectin for the food industry which could be utilized on a gelling agent in jams, confectionary, and bakery fillings and as stabilizers in yoghurts and milk drinks. They used three types of extraction media comprising hydrochloric acid (HCI) deionized water or oxalic acid/ammonium oxalate (OAAO) to extract the pectin from dried alcoholic-insoluble residues (AIR) of golden apple peels. Their study identified golden apple skin or peels as a rich source which could yield up to $30 \%$ of the AIR reported. Depending on the extraction method used, uronic acid contents varied from 557$727 \mathrm{mg}^{-1} / \mathrm{g}^{-1}$ dry weight the degree of methylation ranged from $50-58 \%$ and the molar masses were in the range 563,000-303,000 g/mol. The study also revealed that since molar mass and degree of methylation are important parameters in gel-breaking strength, OAAO golden apple pectins could be useful as food additives. Additionally, the golden apple pectin compared favourably to lime pectins extracted under the same conditions, thereby confirming their commercial significance as "designer" pectin.

\section{Conclusion}

Golden apple fruits of both genetic lines are extremely susceptible to mechanical damage and innovative devices are required to limit losses during harvesting, packinghouse operations and distribution at market outlets. Due to the climacteric pattern of respiration where the ripening process seems to be regulated by $\mathrm{C}_{2} \mathrm{H}_{4}$, appropriate $\mathrm{C}_{2} \mathrm{H}_{4}$ management protocols are necessary such as application of $\mathrm{C}_{2} \mathrm{H}_{4}$ antagonists eg. purafil, 1-methylcyclopropene (1-MCP), as well as controlled atmosphere storage and biotechnological procedures. Major emphasis should be directed towards the use of mature-green fruit in view of the range of value-added options available such as sweet and sour pickles, juices, pie fillings and baby food. Thus, the need to conduct further 
Citation: Mohammed M, Bridgemohan P, Mohamed MS, Bridgemohan RSH, Mohammed Z (2017) Postharvest Physiology and Storage of Golden Apple (Spondias cythera sonnerat or Spondias dulcis forst): A Review. J Food Process Technol 8: 707. doi: 10.4172/2157-7110.1000707

research to extend the shelf life to accommodate marine shipments in view of the escalating costs of air shipments would be well accepted by many food producers at the cottage industry scale of operations who represent or are linked to the main manufacturers of value-added products from this fruit. Further investigations are required to exploit the commercial extraction of pectin from the fruit peel to be utilized as a stabilizer and gelling agent for ice creams, bakery products and confectionery products. Identification, extraction and analysis of enzymes associated with fruit ripening would also be useful to manage softening and textural changes during the ripening process.

\section{References}

1. Bridgemohan $P$ (2017) Market opportunities for golden apple fruits in the Caribbean. Workshop on Exotic Fruits in the Caribbean, Waterloo Research Center, University of Trinidad and Tobago.

2. Morton JF (1961) Why not use and improve the fruitful Ambarella. Horti Adv 5: 13-16.

3. Mohammed M, Wickham LD (1997) Occurrence of chilling injury in golden apple (Spondias dulcis Sonn) fruits. Journal of Food Quality 20: 91-104.

4. Graham OS, Wickham LD, Mohammed M (2004) Growth, development and quality attributes of miniature golden apple fruit (Spondias cytherea Sonn): Fruit growth and development to maturity. Int J Food Agri Environ 2: 90-94.

5. Persad C (1996) Production and marketing of golden apples. Proceedings of the CARDI/CTA Workshop on Marketability of Caribbean Minor Fruits, Port of Spain, Trinidad pp: 89-97.

6. Winsborrow C (1994) Golden apple production. Proceedings of the Third Regional Workshop on Tropical Fruits, Grenada pp: 178-181.

7. Islam SA, Ahmed KT, Manik MK, Wahid MA, Kamal SK (2013) A comparative study of the antioxidant, antimicrobial, cytotoxic and thrombolytic potential of the fruits and leaves of Spondias dulsis. Asian Pac J Trop Biomed 3: 682-691.

8. Fortune M, Dilbar A (1993) New diseases of mango (Mangifera indica), passion fruit (Passiflora edulis var. flavicarpa) and pommecythére (Spondias cytherea) and their treatment to sustainable agriculture. NIHERST, Trinidad.

9. Andall RP, Baldeo S (2000) The effect of fruit and inflorescence pruning on fruit size and yield of dwarf golden apple (Spondias cythera Sonn.). IICA Tropical Fruits Newsletter pp: 12-15

10. Popenoe J (1979) The genus Spondias in Florida. Florida State Horticultural Society, USA 92: 277-279.

11. Ochse JJ, Soule MJ, Dijkman MJ, Wehlburg C (1961) Tropical and subtropical agriculture. Macmillan Press, New York, USA pp: 548-551.

12. Bridgemohan $P$ (2008) Incubator farms as a sustainable approach for 'Neofarmers'. Caribbean Food Crops Society Meeting, University of Florida, IFAS, USA.

13. Bauer T, Kim J, Baldeo I (2003) A preliminary study on the golden apple (Spondias dulcis) production and marketing in Grenada. IICA Miscellaneous Publication Series.

14. Geurts F, Blaak G, El-Baradj T (1986) Anacardiaceae (Spondias cytherea), in Genetic Resources of Tropical and Subtropical Fruits and Nuts (excluding Musa). International Board Plant Genetic Resources, Roma, Italy pp: 18-19.

15. Graham OS, Wickham LD, Mohammed M (2004) Growth, development and quality attributes of miniature golden apple fruit (Spondias cytherea Sonn) Part II: Physicochemical and organoleptic attributes associated with fruit ripening. Int J Food Agri Environ 2: 101-106.

16. Graham OS, Mohammed M, Wickham LD (2004) Effects of heat treatments on the quality of miniature golden apples (Spondias cytherea Sonn) during low temperature storage. Int J Food Agri Environ 2: 43-48.

17. Franquin S, Marcelin O, Aurore G, Reynes M, Brillquet J (2005) Physicochemical characterization of the mature-green golden apple (Spondias cytherea Sonnerat). Fruits 60: 203-210.

18. Franquin S, Marcelin O, Brillouet J (2005) Optimising quality of a mature-green golden apple (Spondias cytherea) drink using amyloglucosidase treatment FRUTIC, Montpellier France pp: 83-90.

19. Mohammed M (2003) Postharvest handling of golden apple (Spondias cytherea). University of the West Indies Extension Fact Sheet.

20. Mohammed M (2017) Training manual on postharvest handling and crop utilization of tropical fruits, vegetables and root crops. Bahamas and Andros Island, Nassau.

21. Daulmerie S (1994) Investigations on golden apple (Spondias cytherea) production with reference to postharvest technology and processing. IICA Miscellaneous Publication Series.

22. Enamorado HEP, Finger FL, Barros RS, Puschmann R (1995) Development and ripening of yellow passion fruit. J Horti Sci 40: 573-576.

23. Graham OS, Mohammed M, Wickham LD (2001) Occurrence of the climacteric pattern of respiration in miniature golden apple (Spondias cytherea) fruit. Proceedings of the 37th Annual Meeting of Caribbean Food Crops Society 37 233-242.

24. Ponte JJ, Athayde C, Sena CB, Vae CC, De Bezerra JL (1988) Aetiology of resinosis of fruit trees of the genus Spondias. Fitopatologica brasileria 13: 280-281.

25. Pruvost O, Luisetti J (1989) Strains of Xanthomonas compestris isolated from the Ambarella (Spondias cytherea Sonn) in the French West Indies are probably a new pathogenic form of Xanthomonas campestris pv. Mangifarae indicae. Fruits 44:530-542.

26. Samson JA (1986) Tropical fruits. Tropical Agriculture Series Publications

27. Ding H (1978) Anacardiaceae. Flora Malesiana 1: 479-483.

28. Singh $\mathrm{P}$, Misram R, Singh $\mathrm{P}$ (1989) Bionomics of the Ambara defoliator Podontia punctata Lin. Indian Forester 115: 910-915.

29. Medlicott AP (1990) Production specifications and postharvest handling for fruits, vegetables and root crops exported from the Caribbean. Caricom Export Development Project Manual, Barbados WI pp: 30-33.

30. Franquin S, Marcelin O, Reynes M (2008) Characterization of starch and cel walls from mature-green Ambarella (Spondias cytherea Sonnerat) and their enzymatic hydrolysis. Europe Food Res Technol 226: 905-913.

31. Koubala BB, Mbome LI, Kansci G, Tehouanguep MF, Crepeau MJ, et al. (2007) Physicochemical properties of pectins from Ambarella peels (Spondias cytherea) obtained using different extraction conditions. Food Chem 106: 1202-1207. 